\title{
Spotify: Aplikasi Music Streaming untuk Generasi Milenial
}

\author{
S. Yollis Michdon Netti, Irwansyah \\ Universitas Pelita Harapan, Universitas Indonesia \\ yollis@gmail.com,dr.irwansyah.ma@gmail.com
}

\begin{abstract}
The large population in Indonesia has become a huge market for many products, including streaming music-based technology products, to reach the target audience of young people. One of the applications that is becoming a trend at the moment is Spotify. A streaming music platform that has many interesting features, and is widely used by millenial generation around the world, including in Indonesia to listen to music. This paper aims to explain clearly and detail about Spotify as the world's largest streaming music platform, how the business model used by Spotify, how Spotify helps musicians to maximize their earnings, how Spotify can change the trend of listening to music from millennials and connoisseurs music around the world, what is the millennial reference for listening to music online, how millennial generation consumes music, history and streaming music technology trends, how Spotify prepares its technology to remain number one, how does music streaming in Spotify, what Just about the online advertising services from Spotify For Brands, how to implement Spotify ads for the brand and ad format used, what brand success stories have used Spotify's advertising services, and how Spotify helps the brand to reach millennials in effective, and how Spotify utilizes technology to be at the forefront of the moment.
\end{abstract}

Keywords: millennial generation, music streamingonline advertising, spotify

\begin{abstract}
Abstrak
Jumlah penduduk yang besar di Indonesia menjadi pasar yang sangat besar bagi berbagai produk, termasuk di dalamnya produk teknologi berbasis musik streaming, untuk menjangkau target audience anak muda. Salah satu aplikasi yang sedang menjadi tren pada saat ini adalah Spotify. Sebuah platform musik streaming yang memiliki banyak fitur menarik, serta banyak digunakan oleh generasi milenial di seluruh dunia, termasuk di Indonesia untuk mendengarkan musik. Tulisan ini bertujuan untuk memaparkan secara jelas dan detail tentang Spotify sebagai sebuah platform musik streaming terbesar di dunia, bagaimana model bisnis yang digunakan oleh Spotify, bagaimana Spotify membantu para musisi di dalam memaksimalkan pendapatannya, bagaimana Spotify dapat mengubah trend mendengar musik dari para milenial maupun penikmat musik di seluruh dunia, apa yang menjadi acuan dari generasi milenial untuk mendengarkan musik secara online, bagaimana generasi milenial mengkonsumsi musik, sejarah dan tren teknologi musik streaming, bagaimana Spotify mempersiapkan teknologinya untuk tetap menjadi nomor satu, bagaimana cara kerja music streaming di Spotify, apa saja layananlayanan periklanan online dari Spotify For Brands, bagaimana implementasi iklan Spotify untuk brand dan format iklan yang digunakan, apa saja kisah sukses brand yang telah menggunakan layanan iklan dari Spotify, dan bagaimana Spotify membantu brand untuk dapat menjangkau generasi milenial secara efektif, dan bagaimana Spotify memanfaatkan teknologi untuk menjadi yang terdepan pada saat ini.
\end{abstract}

Kata Kunci: generasi milenial, iklan online, music streaming, spotify 


\section{Pendahuluan}

Pesatnya perkembangan di bidang teknologi informasi mengakibatkan cara mendengarkan musik mengalami perubahan yang signifikan. Generasi digital saat ini lebih memilih mendengarkan musik secara online melalui perangkat digital mereka. Survey yang dilakukan oleh Asosiasi Penyelenggara Jasa Internet Indonesia (APJII), menunjukan bahwa 35,5\% dari populasi pengguna internet di Indonesia, atau sekitar 46,9 juta orang Indonesia mendengarkan musik secara online (APJII, 2016).

Sebagai sebuah aplikasi musik, Spotify telah menjelma menjadi pemimpin global terdepan dalam hal platform music streaming. Melihat data yang dirilis di situs Spotify.com, saat ini jumlah pengguna berbayar dari Spotify telah mencapai 60 juta pada bulan Juli 2017, dengan pengguna aktif mencapai 140 juta pencinta musik yang tersebar di seluruh penjuru dunia. Berdasarkan infografis yang dirilis oleh AdWeek, sekitar $72 \%$ dari pengguna Spotify adalah generasi milenial (Cummings, 2016).

Generasi milenial telah menjadi pasar terbesar yang mengkonsumsi berbagai aplikasi music streaming seperti Spotify. Hingga November 2017, misalnya, total pengguna Spotify yang telah mengunduh aplikasi mobile versi Android telah mencapai 100 juta orang (Google Play, n.d.). Jumlah penggunanya juga akan terus bertambah, karena penetrasi perangkat telepon pintar yang terus berkembang di Indonesia. Data yang dirilis APJII (2016) menyebutkan bahwa hingga November 2016, jumlah pengguna ponsel pintar telah mencapai 89,9 juta orang, atau $67,8 \%$ dari total populasi pengguna internet di Indonesia.

Sebagai sebuah layanan music streaming yang memiliki pengguna aktif yang besar jumlahnya, Spotify memiliki layanan periklanan online yang disebut dengan Spotify For Brands. Beragam ad format tersedia untuk brand-brand yang ingin menjangkau generasi milenial yang merupakan audience terbesar dari Spotify (SpotifyForBrands.com, n.d.). Spotify juga baru saja merilis sebuah platform audio self-service periklanan baru, yaitu Spotify Ad Studio. Layanan ini memungkinkan pemasar untuk menjangkau konsumen yang tepat pada saat yang tepat, untuk mengelola kampanye beragam audio dengan pilihan anggaran yang fleksibel (Lacy, 2017).

Besarnya jumlah pengguna Spotify pada akhirnya menciptakan trend tersendiri yang terus berkembang seiring dengan pesatnya perkembangan teknologi mobile. Kekuatan Spotify adalah pada standard industri baru yang telah diciptakannya (Osazuwa, 2014). Dengan besarnya jumlah pengguna internet di Indonesia, maka Spotify memiliki pangsa pasar yang sangat besar di Indonesia. Pihak Spotify telah mengumumkan bahwa Indonesia merupakan satu-satunya pasar di Asia dengan pertumbuhan tercepat. Total sudah 3,9 milyar lagu diputar di Indonesia (Triwijanarko, 2017).

Berdasarkan berbagai data-data, fakta menarik dan latar belakang seperti disebutkan di atas, maka penulis tertarik untuk melakukan penelitian tentang Spotify sebagai sebuah media yang dapat digunakan untuk menjangkau generasi milenial, melalui beragam pilihan ad format online yang ada pada fitur Spotify For Brands, menggunakan kekuatan aplikasi Spotify. 
Penelitian tentang aplikasi musik streaming Spotify dirasakan sangat penting untuk dilakukan pada saat ini, mengingat referensi tentang Spotify masih didominasi oleh beragam sumber yang berasal dari mencanegara, termasuk di dalamnya riset-riset dan jurnal yang didominasi oleh penulis yang berasal dari negara-negara di luar Indonesia. Hal penting lainnya adalah masih kurangnya referensi dan jurnal terbaru yang membahas tentang Spotify dan periklanan digital secara umum di Indonesia, bagaimana perkembangan Spotify di Indonesia dan trend lainnya yang sesuai dengan kondisi di Indonesia. Berbagai penelitian terdahulu yang menjadi referensi penelitian ini lebih banyak membahas tentang Spotify dengan berbagai kasus dari negara lain, yang tidak relevan dengan kondisi di Indonesia. Penelitian ini juga menjadi penting karena sebagian besar referensi menggunakan data dan riset terbaru dalam dua tahun terakhir dan dilengkapi dengan data-data terbaru yang dirilis oleh Spotify Indonesia.

\section{Metode Penelitian}

Penelitian ini menggunakan metodologi deskriptif, yang bertujuan untuk menjelaskan secara lengkap tentang Spotify sebagai sebuah platform music streaming, sejarah perkembangan musik digital hingga era music streaming, bagaimana cara generasi milenial dalam mengkonsumsi musik di era digital, dan bagaimana pengiklan menggunakan beragam format iklan yang ada di Spotify untuk menjangkau generasi milenial, termasuk jenis-jenis periklanan online yang ada di Spotify. Penelitian ini tidak mencari atau menjelaskan hubungan, tidak menguji hipotesis, atau membuat prediksi. Metode deskriptif bertujuan melukiskan secara sistematis fakta atau karakteristik populasi tertentu atau bidang tertentu secara faktual dan cermat (Isaac dan Michael, 1981, dalam Rakhmat dan Ibrahim, 2016).

\section{Hasil Penemuan dan Diskusi}

\section{Spotify Sebagai Sebuah Platform Musik Streaming}

Sebelum membahas lebih mendalam tentang music streaming, maka terlebih dahulu bagian ini akan menjelaskan secara singkat tentang sejarah musik digital itu sendiri, yang merupakan cikal bakal dari music streaming yang baru muncul belakangan. Perekam audio digital pertama yang tersedia secara komersial adalah Sony PCM-1. Diperkenalkan pada tahun 1977. PCM-1 mengubah sinyal analog yang masuk menjadi digital, lalu dicatat ke dalam kaset video standard dalam VCR. Pada tahun 1982, untuk pertama kalinya, Sony dan Philips merilis compact disc pertama. Pada CD, informasi digital diwujudkan sebagai jutaan bit mikroskopis pada lapisan alumunium reflektif dari disk. Pemutar CD kemudian menggunakan unit optik untuk membaca pola bit dan mengubah pulsa elektrik yang dihasilkan menjadi sinyal analog ke speaker (Canadian Historical Sound Recording, 2017). Digitalisasi musik dimulai pada tahun 1983, dengan mulai diperkenalkannya compact disc (CD). CD pertama kali dirilis di Jepang, pada bulan Maret 1983, dan berhasil masuk ke Amerika Serikat dan Eropa (Hopewell, 2012). 
Pada awal tahun 1990-an, format MP3 untuk pertama kalinya mulai diperkenalkan kepada publik dengan besaran file yang sebelas kali lebih kecil daripada format sebelumnya, dan memungkinkan untuk dikirim melalui email dan diunduh secara cepat. (Swanson, 2013). Pada akhir tahun 1999, seperti disebutkan oleh Canadian Sound Recording, Remote Solutions memperkenalkan MP3 player pertama yang menggabungkan hard drive magnetik, yang memiliki kapasitas 1.200 lagu. Ini diikuti dua tahun kemudian oleh Apple Computers 'iPod. Kemudian pada tahun 1999 layanan peer to peer (P2P) diperkenalkan pertama kali oleh Napster. Napster adalah platform yang memungkinkan pengguna untuk berbagi dan menukar file musik MP3. (Lamont, 2013). Layanan ini memungkinkan pencinta musik untuk mengakses musik apa pun yang diinginkan secara gratis, dan belakangan bermasalah karena dianggap melanggar undangundang hak cipta.

Setelah format MP3 menyebar di seluruh dunia, layanan music streaming berbasis cloud hadir dan semakin digemari. Sifatnya yang praktis dan lebih efisien menjadi alasan banyak orang menyukai format ini. Spotify adalah salah satu layanan music streaming yang sangat populer saat ini. Spotify adalah layanan streaming musik digital yang memberikan akses ke jutaan lagu, podcast, dan video dari artis yang ada di seluruh dunia (Spotify.com, 2017).

Seiring dengan semakin cepatnya perkembangan teknologi internet, maka audio streaming menjadi populer. Secara singkat, media streaming adalah sebuah proses pengiriman audio, video, atau teks secara terus menerus melalui internet (Illinois Online Network dalam Cox, 2005). Keuntungan dari music streaming yang gratis dan berbayar adalah memberikan layanan yang terus menerus untuk mendengarkan musik yang diinginkan kapan saja, di mana saja dengan cara yang mudah (American University, 2016).

Pada tahun 2005 untuk pertama kalinya ide tentang Spotify dikemukakan oleh pendirinya Daniel Ek dan Martin Lorentzon. Keduanya mengemukakan gagasan tentang layanan Spotify, sambil berbagi musik di antara mereka di sebuah apartemen di Swedia, dan meluncurkan versi beta kepada publik di tahun 2007 (Crook \& Tepper, 2015). Aplikasi resminya diluncurkan pertama kalinya pada tanggal 7 Oktober 2008. Spotify terus berkembang, dan sejak itu berekspansi di lebih dari 56 negara termasuk Amerika Serikat dan Filipina. Dalam perkembangannya kemudian, Spotify mendapatkan perjanjian kerjasama dengan Universal Music Group, Warner Music, EMI Group, Sony Music Entertainment, dan Merlin. (Kiendl, 2014).

Sebagai sebuah platform musik streaming, aplikasi Spotify dapat dijalankan pada berbagai perangkat digital seperti ponsel pintar, desktop, tablet, playstation, xbox, smart tv, hingga perangkat audio berbasis bluetooth. Untuk menjalankan aplikasi Spotify, maka harus mengunduh aplikasi Spotify terlebih dahulu di perangkat yang dimilikinya. Selanjutnya pengguna bebas memilih layanan berbayar (premium) atau layanan gratis. Dengan membayar Rp. 49.900,/bulan, maka pengguna dapat mendengarkan musik secara offline, tanpa iklan, memainkan lagu apa saja, dan mendapatkan kualitas audio yang jauh lebih bagus dari layanan versi gratis (Spotify.com, 2017). 
Spotify memiliki model bisnis campuran antara layanan freemium yang didukung oleh iklan, dan layanan berbayar. Dalam menjalankan bisnis modelnya, komponen biaya terbesarnya adalah biaya penjualan, termasuk di dalamnya biaya untuk pembayaran lisensi musik (Gobry, 2011). Selain layanan berbayar, Spotify juga menggabungkannya dengan layanan freemium yang didukung oleh layanan periklanan. Ada tiga model berlangganan yang dijelaskan di laman Spotify.com, yaitu:

1. Spotify Gratis. Pengguna aplikasi dapat mengunduh dan mendengarkan Spotify secara gratis, dan sebagai gantinya, terdapat layanan periklanan berupa audio dan iklan display.

2. Spotify Premium. Membayar biaya berlangganan sebesar Rp. 49,900,- / bulan (untuk umum), Rp. 24,900,- (untuk pelajar), dan Rp. 79,000,- untuk keluarga, dan mendapatkan lima account (Spotify.com, 2017).

Dalam nejalankan bisnisnya, Spotify bekerjasama dengan berbagai perusahaan rekaman yang membawahi para musisi. Ada banyak skenario pembagian keuntungan antara Spotify dan pihak musisi/label rekaman. Spotify, misalnya mengatakan bahwa pembayaran rata-rata untuk streaming ke label dan music publisher adalah \$0,006 dan \$0,0084. Namun ada juga informasi yang mengatakan pembayaran artis dari porsi label adalah \$ 0,001128 (Dredge, 2015).

Layanan music streaming, seperti yang dimiliki Spotify, telah mengubah wajah industri musik. Beyonce membuat sejarah dengan albumnya Lemonade, yang menghasilkan rekor 115 juta kali didengarkan hanya dalam seminggu. Satu minggu kemudian Drake memecahkan rekor tersebut, ketika albumnya didengarkan lebih dari 245 juta kali. Era musik streaming telah tiba dengan kekuatan penuh, menggantikan penjualan album fisik seperti CD (Luca \& McFadden, 2016) Di garis depan revolusi music streaming, Spotify dan iTunes Music dari Apple - dua "pengganggu" ini berdiri kokoh mengubah cara kita menikmati musik. Keduanya bersama membangun perkembangan dan trend music streaming (Bullhound, 2017).

Untuk memberikan layanan yang prima kepada 140 juta pengguna aktif Spotify, maka salah satu elemen kunci media streaming seperti musik dan video adalah dukungan protokol streaming yang digunakan. Idealnya, data yang ada dikompres sebanyak mungkin lalu ditransfer menggunakan cara yang efisien agar mengurangi kepadatan pada jaringan (Irvine, 2013).

Tingginya kebutuhan akan layanan infrastruktur berbasis cloud yang handal, memaksa Spotify untuk menggunakan layanan terbaik. Untuk infrastruktur server-nya, sejak pertengahan 2016, Spotify menyatakan bahwa pihaknya telah memindahkan teknologi yang menjalankan layanan music streaming-nya ke Google Cloud Platform. Sebelumnya infrastruktur server dari Spotify menggunakan layanan Amazon Web Services (Moon, 2016).

Sebagai penyedia layanan music streaming, Spotify selalu memperbaharui teknologinya dengan tren yang sedang berkembang saat ini. Salah satunya adalah teknologi berbasis Artificial Intelegence (AI), yang berguna untuk memperkuat dominasinya di industri music streaming. AI sendiri adalah sebuah ilmu dan tehnik membuat mesin yang cerdas, khususnya program komputer cerdas. Hal ini 
terkait dengan tugas serupa yang menggunakan komputer untuk memahami kecerdasan manusia, namun AI tidak harus membatasi diri pada metode yang diamati secara biologis (McCarthy, 2007).

Latar belakang itulah yang menyebabkan Spotify aktif melakukan akuisi perusahaan-perusahaan teknologi di bidang musik di sepanjang tahun 2017. Yang terbaru adalah Spotify mengumumkan bahwa startup AI asal Perancis, Niland, telah bergabung dengan jajarannya (Russel, 2017). Niland mengklaim sebagai perusahaan teknologi musik yang menyediakan mesin pencarian dan penemuan berdasarkan algoritma pencarian dan pembelajaran yang mendalam (McIntyre, 2017).

\section{Cara Generasi Milenial Mengkonsumsi Musik}

Biro sensus United Nations mengkategorikan generasi milenial sebagai orang-orang yang lahir pada periode tahun 1982 - 2000 (Genoese, 2016). Generasi milenial disebut juga dengan generasi "Y", sebuah generasi yang sangat aktif menggunakan media sosial. Riset dari The U.S Chamber of Commerce Foundation menyebutkan bahwa generasi milenial dikenal karena kemampuan "multitasking" yang dimilikinya (Genoese, 2016).

Untuk membandingkan generasi milenial dengan generasi-generasi sebelumnya yang terlebih dahulu ada, maka di bawah ini adalah pembagian generasi-generasi yang digambarkan oleh Nielsen (2014): Greates Generation (1901-1924); Silent Generation (1925-1945); Baby Boomers (1946-1964); Generation X (1965-1976); Millenials/Gen (1977-1995) : Younger Millennials (18-27), Older Millennials (28-36); Generation Z (1995-present)

Lebih jauh tentang generasi milenial, dalam riset berjudul Millennials Breaking the Myth (Nielsen, 2014), generasi yang aktif dan dinamis ini memiliki karakter khusus sebagai berikut: (1) Beragam, Ekspresif dan Optimis. Lebih dewasa dari usia mereka. Sebagai sebuah kelompok, mereka lebih beragam secara etnis dari generasi sebelumnya, generasi ini lebih ekspresif dan optimis; (2) Membawa Gerakan Sosial Menuju Kota. Lebih mencari dan menyukai kota-kota yang energik, kreatif dan dinamis yang menawarkan perpaduan permahan, belanja dan kantor tepat di ambang pintu rumah mereka; (3) Pantang Menyerah dan Memiliki Semangat Wirausaha. Menghadapi tingkat pengangguran yang tinggi, mencoba untuk membangun diri mereka sendiri. Sebagian telah berinvestasi pada startup dan berusaha untuk berwiraswasta; (4) Senang Berbelanja dan Menyukai Keaslian. Karena belum memiliki penghasilan yang besar, maka mereka sangat cerdas dalam berbelanja dan selalu mencari sesuatu yang orisinil serta murah; (5) Terkoneksi dan Menyukai Sentuhan Pribadi. Tidur selalu bersama ponselnya, terbiasa memposting status dari ruang pribadi mereka. Lebih menyukai sentuhan pribadi dari brand, dan cenderung mempromosikan brand tersebut jika menyukainya.

Di Indonesia, berdasarkan riset yang dilakukan oleh Asosiasi Penyelenggara Jasa Internet Indonesia (APJII), pengguna internet dari generasi milenial adalah sebesar 63\% dari total pengguna internet di Indonesia yaitu 132,7 juta orang. Mereka mendengarkan musik secara online $(35,5 \%)$, dan menggunakan perangkat mobile sebagai sarana berkomunikasi $(47,6 \%)$. (APJII, 
2016). Hal ini menunjukan bahwa mendengarkan musik secara online adalah sebuah cara generasi milenial mendapatkan hiburan.

Sebagai generasi usia produktif yang aktif menggunakan perangkat teknologi, generasi milenial memiliki beberapa karakter pada saat mencari dan mengakses layanan music streaming di internet. Hal ini dapat dilihat pada riset dari Digital McKinsey, tentang The Beat of Progress: The Rise of Music Streaming in Asia, menjelaskan bahwa generasi milenial lebih menyukai tiga hal. Pertama lokalisasi, penyedia layanan music streaming sebaiknya menyediakan konten lokal sehingga lebih relevan bagi pengguna lokal yang mengakses layanan tersebut. Misalnya bahasa Indonesia, atau artis lokal Indonesia. Kedua, personalisasi, penyedia layanan sebaiknya menyediakan konten musik berdasarkan kesukaan dan preferensi pengguna sehingga lebih personal sifatnya. Dengan demikian akan membuat lebih ekslusif. Misalnya fitur "Your Daily Music" dari Spotify. Ketiga, ramah media sosial, penyedia layanan sebaiknya berkolaborasi dengan media sosial yang ada sehingga memudahkan pengguna untuk mengakses layanan music streaming tersebut. Misalnya login menggunakan identitas sosial media yang sudah ada. (DigitalMcKinsey, 2016)

Banyak karakter dari generasi milenial ketika mendengarkan musik. Latar belakang budaya dan tingkat pendidikan sangat memengaruhi hal ini. Pada sebuah penelitian terdahulu tentang Millennial Music Discovery, menggambarkan dengan jelas tiga karakter dari generasi milenial ketika mengkonsumsi layanan music streaming, yaitu:

1. Routinists. "Play me my favorites". Tipe ini mendengarkan musik setiap hari, namun tidak menyediakan waktu secara khusus untuk menemukan musik terbaru. Hanya mendengarkan musik sesuai suasana hati, dan tak ingin mengetahui lebih selain lagu yang didengarkan. Pendengar musik seperti ini memiliki interaksi yang rendah, lebih memilih layanan gratis, dan daya beli yang rendah.

2. Backtorians."Hungry for information about artists". Mereka menggunakan banyak platform saat mengakses layanan musik yang disukai. Ingin belajar banyak hal tentang artis favoritnya menggunakan media sosial yang ada. Memiliki selera musik yang lebih baik dari orang kebanyakan. Pendengar tipe ini hanya menyukai genre musik tertentu saja, daya beli yang baik, memiliki referensi informasi yang bagus.

3. Songsmiths. "Seeking meaning and connection". Sangat aktif untuk menemukan lagu-lagu terbaru, menyukai sebuah lagu berdasarkan musik dan liriknya, lebih suka berinteraksi dengan langsung dengan artis melalui platform musik daripada sosial media. Tertarik untuk untuk menemukan musik yang memiliki makna mendalam bagi dirinya. Tipe ini menyukai banyak genre musik, memiliki pemikiran yang bebas, mencari informasi musik dari berbagai sumber. (Koerbel, 2016).

Di dalam mengakses informasi di internet, generasi milenial cenderung menggunakan beberapa platform sekaligus, yang pada akhirnya berakibat dengan banyaknya konten yang dikonsumsi (Borron, 2017). Di dalam mengakses konten music streaming, generasi milenial menikmati musik secara berbeda dengan 
generasi sebelumnya. Pendengar berusia muda menghabiskan rata-rata 25 jam setiap minggu untuk mendengarkan music streaming (Roettgers, 2015).

Penyedia layanan music streaming juga turut memengaruhi bagaimana generasi milenial menikmati musik. Spotify, misalnya, yang memiliki fitur personalisasi musik untuk pendengarnya. Itulah sebabnya Spotify memiliki pelanggan terbesar dari generasi milenial. Secara global $72 \%$ dari pengguna Spotify adalah generasi milenial, rata-rata mendengarkan musik selama 143 menit setiap harinya menggunakan perangkat mobile mereka (Cummings, 2016).

Data dari Spotify Indonesia Consumer Insight (2017), menjelaskan secara jelas bagaimana generasi milenial mengkonsumsi konten Spotify, yaitu menjelang tidur (37\%), pada waktu belajar (35\%), saat membersihkan rumah (29\%), bangun tidur (24\%) (Spotify \& Nielsen, 2017). Sedang pada saat melakukan aktifitas belanja online, $19,5 \%$ pengguna Spotify meminta pendapat dari berbagai forum dan media sosial. Sebanyak $10 \%$ pengguna Spotify senang berbelanja produk elektronik, baju, speaker, headphones, gaming consoles, dan bermain game (Spotify \& Kantar TNS Research, 2017).

\section{Bagaimana Memanfaatkan Iklan Spotify untuk Menjangkau Generasi Milenial?}

Generasi milenial adalah kelompok usia produktif yang sangat potensial. Hal ini disadari betul oleh Spotify. Sebagai salah satu penyedia layanan music streaming, Spotify sangat serius menggarap pasar Indonesia. Riset tentang konsumen sering dilakukan dalam rangka mengetahui secara jelas karakter konsumennya di Indonesia. Berdasarkan riset Spotify dan The Nielsen Company, $84 \%$ dari pengguna Spotify adalah generasi milenial, yang berusia antara 15-34 tahun, yang menarik, $60 \%$ pengguna Spotify di Indonesia adalah wanita (Spotify \& Nielsen Research, 2017). Di Indonesia, Spotify hadir pada bulan Maret 2016 lalu. Kehadiran Spotify di Indonesia meramaikan persaingan layanan music streaming yang telah ada. Seperti sudah diketahui, selain aplikasi yang identik dengan warna hijau ini, ada juga iTunes Music, Joox, dan Langit Musik. Dalam melayani konsumen Indonesia, Spotify menawarkan metode pembayaran transfer ATM, internet banking, online payment Doku Walet, hingga membayar melalui jaringan toko waralaba Alfamart (Widiartanto, 2016).

Periklanan online adalah jenis komunikasi massa berdasarkan bentuk iklan tradisional, namun dikembangkan dengan pendekatan strategi komunikasi yang disesuaikan dengan media dan persyaratan teknis yang baru. Singkatnya, periklanan online adalah tentang bagaimana menyajikan iklan kepada pengguna internet melalui website, email, software pendukung iklan, ponsel pintar, termasuk di dalamnya iklan kontekstual yanga ada di mesin pencari (Deshwal, 2016). Kekuatan periklanan terletak pada kecanggihan, kepiwaian dalam merumuskan ataupun mengorganisasikan pesan-pesan menarik perhatian dan mampu membangun pemaknaan bersama antara pengirim pesan iklan dengan khalayak (Susanto, 2014).

Untuk memanfaatkan besarnya pengguna Spotify di Indonesia, yang mayoritas adalah generasi milenial, maka Spotify menghadirkan layanan Spotify For Brands. Layanan periklanan online dari Spotify ini menggunakan pendekatan 
memahami manusia melalui musik. Spotify menganalisis cara lebih dari 140 juta mendengarkan Spotify, serta melakukan survey pendengar di seluruh dunia untuk mengetahui keterkaitan kebiasaan streaming mereka (SpotifyForBrands.com, 2017).

Dalam penelitian terdahulu tentang Online Advertising and Its Impact on Consumer Behavior, Parul Deshwal (2016), menyebutkan manfaat dari sebuah periklanan secara online, yaitu:

1. Lebih Murah. Manfaat terbesar dari periklanan online adalah memiliki harga yang relatif lebih murah jika dibandingkan dengan iklan tradisional. Internet menjangkau lebih banyak audience dengan harga yang relatif murah.

2. Jangkauan Geografis yang Lebih Luas. Periklanan online memberikan jangkauan kampanye globa, yang dapat menjangkau lebih banyak audience. Lebih membantu untuk meraih hasil yang lebih bagus melalui strategi periklanan online.

3. Pembayaran Lebih Fleksibel. Inilah manfaat lain periklanan online yang memungkinkan pengiklan membayar berdasarkan hasil yang diperoleh, misalnya jumlah klik, lead, atau impresi.

4. Hasil Pengukuran yang Mudah. Periklanan online lebih mudah pengukurannya daripada iklan tradisional. Banyak fitur analisis berbasis online yang dapat digunakan untuk mengukur efektifitas sebuah iklan online, dan bagaimana mendapatkan hasil yang maksimal.

5. Target Audience yang Lebih Banyak. Jika dibandingkan dengan iklan tradisional, periklanan online lebih menjangkau target audience yang lebih spesifik yang dapat memberikan kesuksesan yang nyata.

6. Kecepatan. Periklanan online lebih cepat jika dibandingkan dengan iklan tradisional. Dapat secara cepat menjangkau target audience yang besar dengan seketika.

7. Informatif. Periklanan online lebih informatif dan lebih detail dalam menyampaikan pesan kepada target audience, dengan harga yang relatif lebih murah.

8. Hasil yang Lebih Baik. Sejak periklanan online fokus kepada pembayaran berbasis performance, maka hasilnya lebih baik dibandingkan dengan iklan tradisional. Iklan juga dapat dimonitor secara mudah untuk mengontrol kesuksesannya.

9. Keterlibatan Audience yang Mudah. Berbagai platform periklanan online memungkinkan audience untuk berinteraksi dengan sebuah produk iklan, serta mendapatkan feedback langsung.

10. Branding yang Lebih Baik. Beragam bentuk periklanan online yang ada akan membantu meningkatkan merek pengiklan kepada audience yang lebih besar (Deshwal, 2016).

Untuk memberikan layanan periklanan online kepada pengiklannya, Spotify For Brands melakukan strategi unik yang fokus kepada manusia. Di laman SpotifyForBrands.com, disebutkan pendekatan "Memahami Manusia Melalui Musik", yaitu bagaimana Spotify menganalisa kebiasaan mendengarkan 140 juta 
pendengarnya, dan memberikan solusi periklanan yang relevan dengan target audience yang diinginkan. Strategi tersebut menghasilkan tiga karakter pendengar yang dapat dituju oleh pengiklan yang ingin memanfaatkan layanan periklanan Spotify, yaitu:

1. Generasi Milenial. Sangat terlibat, berpengaruh, dan pendengar yang cerdas. Selalu menjadi yang terdepan di antara teman-temannya yang menonton film atau serial TV terbaru. Cara termudah menjangkau mereka adalah melalui konten video yang memikat.

2. Penggemar Fitness. Mereka adalah pelari yang berkonsentrasi, dan pendengar yang mengikuti selera kebanyakan. Selalu menikmati minuman berenergi, membeli dengan dorongan hati, dan menonton video kesehatan dan kebugaran. Untuk dapat menjangkau mereka adalah dengan memperkuat momen. Gunakan video native moment untuk menjangkau mereka (layanan ini hanya tersedia di wilayah tertentu).

3. Penyuka Pesta. Menyukai game hingga pesta di lantai dansa. Sering menonton konser dan membeli buku, menggunakan musik untuk memperbaiki suasana hati, dan membeli barang secara online. Cara menjangkau mereka adalah dengan iklan audio berenergi tinggi yang sesuai dengan konteks real time. Prioritaskan pada genre musik yang semangat, serta menargetkan agenda pesta untuknya. (SpotifyForBrands.com, 2017).

Untuk memberikan beragam layanan periklanan berbasis audio yang ekslusif kepada pengiklan di Indonesia, maka Spotify For Brands menghadirkan sepuluh ad format ekslusif di aplikasi Spotify non premium. Berikut ini adalah ad format dari Spotify For Brands, seperti yang disebutkan di laman SpotifyForBrands.com:

1. Branded Moments. Untuk membangun kedekatan merek dan menciptakan nilai lebih bagi audiens dengan cara beresonansi, memanfaatkan kecerdasan streaming Spotify, dan memberi kesempatan kepada brand untuk terlibat dengan pendengar di saat yang pas.

2. Sponsored Playlist. Memungkinkan untuk memaksimalkan kesdaran akan merek dengan mensponsori playlist Spotify secara ekslusif. Pengiklan akan terhubung dengan pendengar di playlist favoritnya.

3. Sponsored Session. Menjadi pintu gerbang menuju pengalaman music streaming bagi pendengar Spotify versi gratis untuk mendengarkan musik tanpa iklan selama 30 menit. Sebagai imbalannya, maka pendengar akan menonton video ekslusif pengiklan.

4. Video Takeover Everywhere. Memberikan layanan iklan video untuk pendengar di perangkat mobile dan desktop. Video dijamin Human Audible dan Visible on Complete yang diukur oleh MOAT.

5. Audio. Mengjangkau target audience di semua perangkat dari pendengar, di semua tempat, kapan saja, iklan akan ditampilkan di antara jeda lagu sehingga lebih efektif. 
6. Homepage Takeover. Layanan ini akan menampilkan brand pengiklan secara menarik ketika pendengar mengakses aplikasi Spotify. Format ini hanya untuk pendengar yang menggunakan fasilitas desktop.

7. Overlay. Jenis iklan yang sangat kelihatan dan muncul saat pendengar kembali ke halaman utama Spotify. Untuk pendengar yang menggunakan fasilitas desktop dan perangkat mobile.

8. Leaderboard. Menggunakan standard IAB (Interactive Advertising Bureau) banner, dan tampil selama 30 detik. Iklan dapat diklik menuju ke website pengiklan.

9. Branded Playlist. Sangat efektif untuk membangun brand pengiklan di playlist Spotify, dengan menyajikan daftar lagu yang sesuai dengan minat pendengar.

10. Advertise Page. Memungkinkan Spotify untuk mengintegrasikan merek pengiklan di aplikasi Spotify secara menarik. Dapat menampilkan konten pengiklan, blog, berita, hingga video. (SpotifyForBrands.com, 2017).

Hingga saat ini, brand-brand multinasional banyak yang telah memanfaatkan keunggulan dan fitur periklanan online yang dimiliki oleh Spotify. Di laman SpotifyForBrands.com, pada kategori Success Stories, Spotify menyajikan berbagai informasi kisah sukses dari pengiklan yang telah memanfaatkan Spotify untuk menjangkau target audience mereka. Di antaranya adalah Adidas, BMW, Volvo, Reebok, McDonalds, Samsung, Sony Pictures, hingga Puma.

Ketika Adidas melakukan kampanye The Adidas All Originals Campaign, mereka mencoba untuk mendefinisikan arti kreatifitas dari konsumennya, dan apa yang menjadi tujuannya. Pada kampanye ini, pengguna Spotify diminta untuk menambahkan lagu pada playlist tersebut, serta menandainya agar dapat memenangkan voucher belanja Adidas dan berlangganan Spotify premium. Kampanye ini bertujuan untuk meningkatkan kesadaran merek Adidas, dan pada akhirnya diharapkan dapat menggunakan produk-produk Adidas. Hasilnya, lebih dari 30 ribu pengguna Spotify mengunjungi halaman iklan Adidas, 3000 lagu ditambahkan di playlist Adidas, dan lebih dari 700 pengguna Spotify ditandai di halaman Facebook (SpotifyForBrand, 2017).

Kampanye Ford Fiesta: Emerge, yang bertujuan untuk meningkatkan kesadaran dari pengguna Spotify terhadap mobil terbaru dari Ford Fiesta. Strategi yang digunakan adalah Ford dan Spotify memperkenalkan 10 artis pendatang baru, untuk membagi konten mereka kepada pengguna Spotify, melalui fitur Spotify Stream dan media sosialnya (Facebook, Twitter, Instagram). Artis terbaik yang mencapai puncak tanggalagu akan memenangkan hadiah berupa konser untuk penggemarnya. Hasilnya adalah lebih dari 118,000 pengguna Spotify mengunjungi halaman iklan Ford Fiesta: Emerge, 13,000 share di media sosial, 139,000 artis stream melalui aplikasi Spotify, dan mendapatkan 2,300 playlist subscriber (SpotifyForBrands.com, 2017).

Sebagai sebuah media berbasis aplikasi music streaming, Spotify harus menyajikan kombinasi layanan iklan yang dapat menarik perhatian penggunanya yang sibuk mendengarkan musik. Dari beragam jenis iklan dari Spotify For 
Brands, seperti yang telah dijelaskan di atas, maka terlihat bahwa perhatian (attention) memiliki peran yang sangat vital dari keberhasilan sebuah iklan online. Perhatian adalah alokasi sumber daya mental, yang bersifat visual maupun kognitif. Sebelum konsumen terpengaruh oleh sebuah pesan iklan, maka terlebih dahulu harus mencurahkan perhatiannya (Teixeira, 2014).

Musik adalah Bahasa yang universal, unik, bersifat personal, dan emosional. Mirip dengan layanan iklan dari Google, aplikasi music streaming Spotify didedikasikan khusus untuk memberikan pengalaman yang relevan untuk penggunanya yang beragam. Dengan segala informasi yang dikumpulkan oleh Spotify, pengiklan dapat menghadirkan iklan yang sangat personal sehingga dapat menarik minat pendengar Spotify pada saat yang tepat (Cuskey, 2017).

\section{Simpulan}

Layanan music streaming telah mengubah wajah industri musik dunia. Sebagai salah satu penyedia layanan music streaming, Spotify telah menjadi penolong bagi banyak perusahaan rekaman maupun artis untuk menjual produk musiknya dengan jangkauan yang lebih luas. Masyarakat pencinta musik di seluruh dunia juga semakin dimanjakan oleh layanan Spotify yang memiliki koleksi musik hingga 30 juta lagu (Spotify.com, 2017). Hal ini berbeda ketika pada tahun-tahun awal kehadiran music streaming, diejek oleh banyak musisi dan pengamat musik sebagai paku terakhir untuk peti mati industri musik (EllisPetersen, 2017).

Sebagai sebuah platform music streaming terbesar pada saat ini, akhirnya membentuk komunitas pengguna Spotify yang tersebar di berbagai penjuru dunia, termasuk di Indonesia. Komunitas yang turut membangun platform Spotify, dan membentuk ekositem music streaming. Hingga Desember 2017, misalnya, total member aktif di komunitas Spotify seperti disebutkan di laman Spotify.com, adalah sebanyak 6,4 juta orang. Sedangkan total jumlah pengguna aktif hingga saat ini adalah 140 juta orang. Seperti yang disebutkan di laman The Spotify Community, Ada tiga komunitas yang menjadi fokus Spotify untuk didukung pengembangannya, yaitu:

1. Komunitas Artis (Spotify for Artists). Dibentuk untuk mendukung komunitas artis/musisi untuk terkoneksi ke aplikasi Spotify. Dapat mengelola profil artis, mengetahui secara jelas pendengarnya, bekerjasama dengan Spotify untuk mendapatkan dukungan.

2. Komunitas Developer (Spotify Developer). Mendukung developer untuk dapat mengembangkan Application Program Interface (API) dari Spotify, developer showcase, design resources, Web API Console, Spotify Play Button, Spotify Android SDK, integrasi Spotify Connect, dan sebagainya.

3. Komunitas Brands (Spotify for Brands). Tema utamanya adalah untuk memahami manusia melalui musik, info beragam format iklan untuk kampanye dari brand, success stories, hingga berita terbaru (Spotify.com, 2017). 
Bagi brand yang ingin menjangkau generasi milenial untuk melakukan kampanye periklanan, maka Spotify adalah pilihan yang dapat dipertimbangkan. Spotify Business Marketing Global Director, Jeff Rossi, menjelaskan bahwa sebagai layanan streaming global terbesar, Spotify memiliki pemahaman yang mendalam tentang generasi milenial berdasarkan data-data tentang kebiasaan streaming mereka (Cummings, 2016). Cerita sukses pengiklan yang telah menjalankan kampanye periklanannya di aplikasi Spotify dapat menjadi acuan bagi brand yang ingin menjangkau generasi milenial secara efektif, melalui musik.

\section{Ucapan Terima Kasih}

Riset tentang Spotify: Aplikasi Music Streaming untuk Generasi Milenial ini dapat terlaksana karena dukungan dari berbagai pihak, khususnya dari Bp. Dr. Irwansyah, MA untuk materi dan referensi menariknya pada mata kuliah Komunikasi, Teknologi dan Masyarakat, di Program Magister Ilmu Komunikasi, Universitas Pelita Harapan (UPH).

\section{Daftar Pustaka}

American University. (1 Februari 2016). How Streaming is Changing The Music Industry. AudioTechnology Blog. American University. Blogs.American.edu. Diakses dari: http://au.blogs.american.edu/audiotechnology/how-streaming-is-changing-the-music-industry. (27 November 2017)

APJII. (2016). Penetrasi \& Perilaku Pengguna Internet Indonesia. Survey.

Borron, A. (5 Oktober 2017). What Millennial Content Consumption Means for The Music Industry. KobaltMusic.com. Diakses dari: https://www.kobaltmusic.com/blog/what-millennial-consumption-habitsmean-for-your-music (29 November 2017)

Cox, J.E. (2005). Music Across Campus: A Study of Streaming Technology Use in Iowa Academic Libraries. Music Reference Sevices Quarterly, Vol.9, No.2 (2005). P.25-41. (29 November 2017)

Crook, J., Tepper, F. (29 Juli 2015). A Brief History of Spotify. TechCrunch.com. Diakses dari: https://techcrunch.com/gallery/a-brief-history-of-spotify/ (27 November 2017)

Cummings, C. (17 April 2016). Infographic: 72\% of Spotify Listeners Are Millennials. Here's How They Use the Service. AdWeek.com. Diakses dari: $\quad$ http://www.adweek.com/brand-marketing/infographic-whatmarketers-need-know-about-millennials-music-habits-170869/\#/ November 2017)

Cuskey, P. (7 Agustus 2017). 7 Reasons to Start Advertising on Spotify. ThatAgency.com. Diakses dari: http://blog.thatagency.com/7-reasons-tostart-advertising-on-spotify (27 November 2017) 
Deshwal, P. (2016). Online Advertising And Its Impact on Consumer Behaviour. International Journal of Applied Research. Vol.2. Isue 2. 200-204.

Digital McKinsey Report. (2016).The Beat of Progress: The Rise of Music Streaming in Asia. McKinsey Company. 5-6.

Dredge, S. (3 April 2015). How Much Do Musicians Really Make From Spotify, iTunes, and Youtube?. TheGuardian.com. Diakses dari: https://www.theguardian.com/technology/2015/apr/03/how-muchmusicians-make-spotify-itunes-youtube (27 November 2017)

Ellis-Pettersen, H. (25 April 2017). How Streaming Save The Music: Global Industry Revenue Hit £12bn. TheGuardian.com. Diakses dari: https://www.theguardian.com/business/2017/apr/25/2016-marks-tippingpoint-for-music-industry-with-revenues-of-15bn (27 November 2017)

Genoese, A.N. (2016). Millennials as Consumers: Can Business Survive As Is?. Thesis Business Administration. University of San Diego.

Gobry, P.E. (12 Oktober 2011). How Spotify's Business Works. BusinessInsider.com. Diakses dari: http://www.businessinsider.com/howspotifys-business-works-2011-10/?IR=T (27 November 2017)

Google Play Store. (n.d). Aplikasi Spotify Music. Play.Google.com. Diakses dari: https://play.google.com/store/apps/details?id=com.spotify.music November 2017))

GP. Bullhound Report (2017). Spotify: \$55 bn by 2020. GP. Bullhound.com. Diakses dari: https://www.gpbullhound.com/wpcontent/uploads/2017/10/GP-Bullhound-Spotify-Update-October-2017.pdf (1 Desember 2017)

Hopewell, L. (17 Agustus 2012). The History of The Compact Disc. Gismodo.com. Diakses dari: https://www.gizmodo.com.au/2012/08/thehistory-of-the-compact-disc/ (27 November 2017)

Irvine, M. (2013). CCTP 797: Technology, Theory, Culture. Blog Georgetown University. Blogs.commons.Georgetown.edu. Diakses dari: https://blogs.commons.georgetown.edu/cctp-797-fall2013/ (29 November 2017)

Isaac, S. \& Michael. (1981). Handbook in Research and Evaluation. San Diego: Edit Publishers.

Kiendl, W. (Mei 2014). Spotify's Time. Music Business Journal (Berklee College of Music). TheMBJ.org. Diakses dari: http://www.thembj.org/2014/05/spotifys-time/ (30 November 2017)

Koerbel, L. (2016). Millennial Music Discovery. Libby Koerbel Research. Kellogg School of Management.7-9.

Lacy, L. (September 20, 2017). Spotify Launches Its Own Self-Serve Platform for Audio Ads. TheDrum.com. Diakses dari: http://www.thedrum.com/news/2017/09/20/spotify-launches-its-own-selfserve-platform-audio-ads (28 November 2017)

Lamont, T. (24 Februari 2013). Napster: The Day The Music Was Set Free. TheGuardian.com. Diakses dari: https://www.theguardian.com/music/2013/feb/24/napster-music-free-filesharing (29 November 2017) 
Library and Archives Canada. (n.d). Canadian Historical Sound Recording. CollectionsCanada.gc.ca. Diakses dari: https://www.collectionscanada.gc.ca/gramophone/028011-3021.4-e.html (28 November 2017)

Luca, M., McFaden, C. (12 Desember 2016). How Streaming Is Changing Music (Again). Harvard Business Review. HBR.org. Diakses dari: https://hbr.org/2016/12/how-streaming-is-changing-music-again November 2017)

McCarthy, J. (2007). What Is Artificial Intelegence?. Standford University. Standford.edu. Diakses dari: http://wwwformal.stanford.edu/jmc/whatisai/whatisai.html. (29 November 2017).

McIntyre, H. (18 Mei 2017). Spotify Has Acquired Machine-Learning Startup Niland. Forbes.com. Diakses dari: https://www.forbes.com/sites/hughmcintyre/2017/05/18/spotify-hasacquired-machine-learning-startup-niland/\#1f2fa9643792 (29 November 2017).

Moon, M. (24 February 2016). Spotify is Moving Its Data to Google Cloud Platform. Endgadget.com. Diakses dari: https://www.engadget.com/2016/02/24/spotify-moving-data-to-googlecloud-platform/ (29 November 2017).

Osazuwa, C., Simantel, B., deFerrari, D., (Agustus, 2014). Spotify And Streaming Music Analysis. ChristineOsazuwa.com. Diakses dari: http://christineosazuwa.com/portfolio/spotify-and-streaming-musicindustry-analysis/ (29 November 2017)

Rakhmat, J., Ibrahim, I.S., (2016). Metode Penelitian Komunikasi - Edisi Revisi Kedua. Bandung, Remaja Rosdakarya.

Roettgers, J. (25 September 2015). Vevo, Pandora and Spotify Top Streaming Music Services for Millennials (Exclusive). Veriety.com. Diakses dari: http://variety.com/2015/digital/news/vevo-pandora-and-spotify-topstreaming-services-for-millennials-exclusive-1201602140/ (27 November 2017).

Russel, J. (19 Mei 2017). Spotify Buys AI Startup Niland to Develop Its Music Personalization and Recommendations. TechCrunch.com Diakses dari: https://techcrunch.com/2017/05/18/spotify-buys-ai-startup-niland/ November 2017)

Spotify \& Kantar TNS Research. (2017). The New Audio Study: Reaching The Spotify Listeners In Indonesia. Spotify For Brand.

Spotify \& The Nielsen Company. (2017). Spotify Indonesia Consumer Insight: Reach The Audience That Matters to Your Brand. Spotify For Brand.

Spotify For Brands. (n.d). Memahami Manusia Melalui Musik. SpotifyForBrands.com. Diakses dari: https://spotifyforbrands.com/id/feature/streaming-habits/ (28 November 2017)

Spotify For Brands. (n.d). Spotify For Brands - Formats. SpotifyForBrands.com. Diakses dari: https://spotifyforbrands.com/us/formats/ (30 November 2017). 
Spotify For Brands. (n.d). Spotify Formats. SpotifyForBrands.com. Diakses dari: https://spotifyforbrands.com/id/formats/ (28 November 2017)

Spotify For Brands. (n.d). Spotify Kisah Sukses. SpotifyForBrands.com. Diakses dari: https://spotifyforbrands.com/id/gallery/ (28 November 2017)

Spotify Indonesia. (n.d). Spotify Premium. Spotify.com. Diakses dari: https://www.spotify.com/id/premium/?checkout=false $\quad(28$ November 2017)

Susanto, E.H. (2014). Dinamika Pesan Iklan. Jurnal Komunikasi UNTAR (Vol.6, No.2, 2014). Journal.untar.ac.id. Diakses dari: https://journal.untar.ac.id/index.php/komunikasi/article/view/28 (27 April 2018)

Swanson, K. (2013). A Case Study of Spotify: Exploring Perceptions. Journal of Music \& Entertainment Industry Educator Association. Volume 13, Number 1 (2013). Belmont University. (29 November 2017)

Teixeira, T.S. (2014). The Rising Cost of Consumer Attention: Why You Should Care, and What You Can Do About It. Harvard Business School. Working Paper. 14-055. 2014. 1.

The Nielsen Company. (2014). Millennials - Breaking The Myths. 3.

Triwijanarko, R. (22 Mei 2017). Tak Mau Disalip Kompetitor, Spotify Kembangkan Teknologi AI. Kompas.com. Diakses dari: http://marketeers.com/spotify-kembangkan-teknologi-ai/ (30 November 2017)

Yoga, Y.H. (30 Maret 2016). Spotify Sudah Bisa Diakses di Indonesia. Kompas.com. Diakses dari: http://tekno.kompas.com/read/2016/03/30/08535267/Spotify.Sudah.Bisa.D iakses.di.Indonesia (27 November 2017) 